UDC 81'255=111=161.2:81'276.6

DOI https://doi.org/10.24919/2308-4863/40-1-14

\author{
Alla BOLOTNIKOVA, \\ orcid.org/0000-0003-4781-7475 \\ Candidate of Philological Sciences, Associate Professor, \\ Head of the General Linguistics and Foreign Languages Department \\ National University "Yuri Kondratyuk Poltava Polytechnic" \\ (Poltava, Ukraine) a.p.bolotnikova@gmail.com
}

Viktor CHERNYSHOV, orcid.org/0000-0002-0960-8464

Candidate of Philosophical Sciences, Associate Professor, Associate Professor at the General Linguistics and Foreign Languages Department National University "Yuri Kondratyuk Poltava Polytechnic" (Poltava,Ukraine) prepod.pntu@gmail.com

Halyna TALOVYRIA, orcid.org/0000-0003-2667-8382 Candidate of Pedagogical Sciences, Associate Professor (Poltava,Ukraine) schoolenho@gmail.com

\title{
PECULIARITIES OF ENGLISH-UKRAINIAN OFFICIAL BUSINESS STYLE TEXTS TRANSLATION
}

\begin{abstract}
The paper focuses on the functioning peculiarities of official business style texts and the techniques of their translation. The authors emphasize that translating the official business style texts it is essential to hold a precise and concise style of expression. Observing strict linguistic standards in official business style of the target language allows the translator to solve complicated problems of business communication. Researches on the peculiarities of the official business style texts translation enables a statement on notorious difficulty of this style, translating of which requires particular attention, much learning, erudition, and large background knowledge. The clarity of information in a translated official document, unambiguity of its content depends on the quality of its translation. It is made clear that one of the major translator's problems in translating documentation and its terminological units is the polysemy in the official business discourse. The extremely important task for the translator, therefore, is to find the corresponding equivalents in the target (in this case Ukrainian) language. The authors state that the official business texts presuppose a standardisation of linguistic means (idioms, cliché, complex cliché constructions), using which one may achieve the syntactic and semantic formalisation of the text. The authors state that translating is a complex process in which it is very important that the translator's skills must be completed with the lingo-cultural knowledge, taking into consideration the interrelation of contacting cultures. It is emphasised that phraseological units, used in the official business texts, are mostly neutral. The authors note that translating of the official business documents, related to the enterprise commercial activity, it is essential to guarantee the correct use of semantic equivalents of the terms, the context translation, and interpretation of diverse abbreviations and acronyms. Creating and functioning of abbreviations and acronyms help using the language in a more economical, comprehensive and informative way, and making the content clearer in general. Business style overall is characterised by increasing standardisation and unification of the language, usage of idioms, clichés, and idiomatic constructions.
\end{abstract}

Key words: clichés, complex language, English-Ukrainian translation, idioms, the official business style.

Алла БОЛОТНІКОВА, orcid.org/0000-0003-4781-7475 кандидат філологічних наук, доцент, завідувач кафедри загального мовознавства та іноземних мов Національного університету "Полтавська політехніка імені Юрія Кондратюка» (Полтава, Украӥна) a.p.bolotnikova@gmail.com

Віктор ЧЕРНИШОВ, orcid.org/0000-0002-0960-8464 кандидат філософських наук, доцент,

дочент кафедри загального мовознавства та іноземних мов Національного університету «Полтавська політехніка імені Юрія Кондратюка» (Полтава, Україна) prepod.pntu@gmail.com 
Галина ТАЛОВИРЯ,

orcid.org/0000-0003-2667-8382

кандидат педагогічних наук, дочент

(Полтава, Україна) schoolenho@gmail.com

\title{
ОСОБЛИВОСТІ АНГЛО-УКРАЇНСЬКОГО ПЕРЕКЛАДУ ТЕКСТІВ ОФІЦІЙНО-ДІЛОВОГО СТИЛЮ
}

\begin{abstract}
Статтю присвячено особливостям функціювання текстів офіційно-ділового стилю та особливостям їх перекладу. Наголошено, щуо у процесі перекладу текстів офіційно-ділового стилю варто дотримуватись точності та стислості викладу. Дотримання тих чи тих мовних норм в офіційно-діловому стилі мови перекладу допоможе фахівиеві розв 'язувати складні проблеми ділового спілкування. Дослідження особливостей перекладу текстів офіиійно-ділового стилю дає підстави стверджувати, щуо ичей стиль є одним із найважчих, тому потребує від фахівия уважності, обізнаності, ерудованості та фонових знань. Від якості перекладу офіиійного документа залежить ясність інформації, яку містить документ, відсутність двозначності. 3'ясовано, що однією з основних проблем перекладу термінів документів та термінологічних одиниць є багатозначність в межах офіційноділового дискурсу. Тому надзвичайно важливим завданням у процесі перекладу документів є пошук відповідних українських еквівалентів. Авторами виокремлено, щзо офіціийн-ділові тексти передбачають стандартизацію мовних засобів (кліше, мовні штампи або клішовані конструкиії), за допомогою яких досягають синтаксичної $i$ семантичної формалізація тексту. Установлено, щуо процес перекладу фразеологічних одиниць є складним проиесом, у якому, крім власної майстерності перекладача, важливими є лінгвокультурні знання, узаємини контактуючих культур. Акиентовано, щзо фразеологічні одиниці, які використовуються в текстах офіційно-ділового стилю, здебільшого нейтральні. Звернуто увагу на те, щчо у процесі перекладу офіційно-ділових текстів, які супроводжують процес комериійної діяльності підприємства, необхідним є правильне використання семантичних еквівалентів термінів, контекстний переклад та тлумачення різних скорочень. Крім того, увагу приділено абревіатурам та скороченим словам, створення та функціонування яких сприяє мовній економії і робить зміст більш зрозумілим та інформативним. Загалом діловий стиль характеризується зростаючою стандартизачією й уніфікацією мови, вживанням сталих словосполучень, мовних кліше, застосуванням фразеологізмів.
\end{abstract}

Ключові слова: офічійно-діловий стиль, англо-український переклад, фразеологізми, мовні штампи, мовні кліше.

Problem statement in general and its connection with important scientific problems. The contemporary state of social development tightly bound with an increasing number of international ties and collaboration, which makes constant demands for the timely and correct information exchange that allows reducing economic expenses, maintaining the effective intercultural communications, coordinating the international activities. Translating business documentation traditionally requires following the strict rules and phrasal clichés: the translator, therefore, should be closely acquainted with the rules and specifics of business correspondence, have the skills and habits of business etiquette.

Translating of the official business texts is one of the most complex processes of translating, since it requires much erudition and versatile knowledge, close acquaintance with the theory of discourse, semantics, large background knowledge, and wide translator's competences. For instance, the translation of a contract cannot be correctly achieved if the translator's knowledge is limited with the areas of law, economics and specifics of record-keeping only. There is also necessity for the knowledge in the field of business, awareness of the terminology in the source and target language.
Review of the most recent researches and publications that contribute to solving of the problem. Translation theorists note that the translation of official business documents must be concrete, precise, brief, clear, and the text of translation in the target language must not contain the syntactic structures of the source language, it must meet the common requirements of the target language (Арсентьева, 1993; Влахов, Флорин, 2009; Шевина, 2010; Kutateladze, 2014 et al.). Among the most recent and valuable researches, dedicated to general peculiarities of the official style texts translation that contribute the present study, there are should be mentioned works by M. Bukulova, E. Henish, M. Kutateladze, A. Roh, A. Shevina, and some others. The official business texts of English-speaking discourse are defined in a different way, according to their research area. This problem is wide and covers all the linguistic aspects that the business activity can offer in written or oral form, which encompass the vocabulary of business, trade, finances, and international affairs, typical business communications, such as presentations, negotiations, meetings, correspondence or producing reports (Kutateladze, 2014: 27).

Setting out the parts of the general problem that have not been solved before and at solving of 
which aims the present paper. Due to the widening of international contacts, there appeared a necessity of performing communicative business tasks. Business communication, correspondence and documentation ensure functioning of economic relations between the agents of management of different countries. One of the major problems that arise between the international companies is the competent composing and translating of documentation, concerning their commercial activity. Business relations, the seriousness of the contracting parties and the level of their obligations depend on how clearly, correctly and competently this or that document will be composed. A competently composed business document is an essential for the efficient and safe cooperation of all parties and each single participant. The translation quality of each official document determines the clarity of information and its unambiguity. An increasing role of international economic relations as well as the necessity of the adequate translation of official documents for business, commercial, financial and other activities witness the relevance of the present study.

Purpose statement and the objective of the present paper. The purpose of the present study is to determine the functioning peculiarities of official business style texts and the specifics of their translation.

General study. One of the major defining features of the business style is that the words are used in their direct lexical meaning. It should be noted that translating the official business style texts, the translator should not allow or admit any emotional connotation, contextual meanings or simultaneous realisation of different meanings of the same word. Language templates and cliches, which may seem odd in the spoken English, are broadly in use in business documentation: e.g. evaluation.

A translation theorist A. Shevina speaks of two basic features of the official business style: «the content which is rendered in official business style, due to its considerable importance, must exclude any ambiguity and avoid any possible differences of interpretation; the official business style is characterised by a very limited circle of subjects» (Шевина, 2010: 13). Beside that, the official business style, according to the scholar, is characterised by the following:

1) strict language regulations (limited set of the means of expression and the ways they are to be used);

2) officiality (rigor of presentation: words are usually used in their literal meanings, imagery is usually absent, tropes are very rare);

3) impersonality (official business language avoids anything concrete or personal) [ibidem].

The precision as a stylistic feature of the official business style, first of all, finds its expression in the use of specific terminology. The use of phraseological units, clichés and patterns is characteristic for business papers. We come across phraseological units and terms in reports, statutes, laws, notes, yet every area has its specific terminology. For instance, in financial, economic and business documents, there are such terms as: liability to profit tax, extra revenue; in diplomatic terminology: to ratify an agreement, memorandum, pact; in legislative documents is a frequent use of phraseological clichés such as: judicial organ, the international court of justice, summary procedure, to hear a case, right of appeal.

In the official business style, idioms are used in office, legislative, and diplomatic documents. In business speaking there is certain standardisation. Idioms are being used in direct and precise meaning, which does not allow any ambiguity.

Business papers have a strict tendency to use the traditional language, which is also characteristic for the style of official papers in English in general, applying a considerable number of archaisms and archaic idioms: henceforth (from now on); aforesaid (mentioned above); beg to inform (ask to inform).

Common to all types of business style is the presence of abbreviations and acronyms: MP (Member of Parliament), UN (United Nations), gvt (government), pmt (Parliament), DAS (Department of Agriculture, Scotland), ANC (African National Congress), BE (Bank of England), EEC (European Economic Community), EU (European Union), NATO (North Atlantic Treaty Organization); the same as in Ukrainian: ККД (коефіиієнт корисної діï - efficiency factor), МВФ (Міжнародний валютний фонд-International Monetary Fund), НБУ (Наиіональний банк України National Bank of Ukraine), ТОВ (товариство з обмеженою відповідальністю - limited liability сотрапу).

The official business style also makes use of Latinisms, which gain a kind of terminological colouring in the language of diplomatic papers: Ad honores (Lat.) - for honour; free of charge; Ad litteram / Ad verbum (Lat.) - literary, directly as it has been said; Cito (Lat.) - urgent, quickly, fast; Et cetera / Etc. (Lat.) - and the rest, and others, and so forth. With the use of this vocabulary the business style achieves its homogeneity and uniformity in writing.

The official style does not allow the use of any expletives or swearwords, colloquialisms or jargonization, yet, in business correspondence sometimes one can come across some professional jargon or vocabulary that circulates in colloquial everyday style: e.g., $H R$ (for the human resources manager) in English or кадровик (начальник або співробітник відділу кадрів або подібного підрозділу) in Ukrainian, платіжка (платіжне доручення, invoice) etc. 
Theorists and practicians of translation S. Vlakhov and S. Florin note that «the possibility of the adequate translation of a phraseological unit depends on the correlation between the units of the source language and the target language:

1) in case a phraseological unit has the precise correspondence (meaning + connotation) in the target language, which does not depend on the context, so that the phraseological unit of the source language which is equal to the phraseological unit in the target language can be translated with the equivalent;

2 ) in case a phraseological units can be translated in the target language with this or that equivalent, as usual with a deviation in meaning or connotation (or both), that is the phraseological unit in the source language, which is approximately equal to the phraseological language in the target language, can be translated by analogy;

3) in case a phraseological unit does not have in the target language either equivalents or analogies, that is the phraseologicalunitof the sourcelanguageisunequal or inadequate to the phraseological unit in the target language, it can be translated with other, non-phraseological means» (Влахов, Флорин, 2009: 190).

The basic way to translate phraseological units which have interlanguage correspondence is the translation with help of an equivalent (fully or partially corresponding), analogy. By interlanguage phraseological equivalents we understand the semantically equivalent phraseological units in different languages which are characterised with the same structural and grammatical organisation and the number of components.

Following O. Arsentieva we distinguish two types of correspondence or equivalence: «full equivalence, that is the full correspondence to the plane of expression and the plane of content of phraseological unit, sameness of phraseological meaning, structural and grammatical organisation, and the component set of correlated units; partly equivalence, which is characterised by insignificant differences in the plane of expression of a phraseological unit of the same semantics» (Арсентьева, 1993).

Full equivalents are represented in English and Ukrainian by phraseological units which share the sameness of significant-denotative and connotative macrocomponents of meaning, identical structural and grammatical organisation and component composition: nuтеrical superiority - чисельна перевага, all the essential conditions of a contract-yci iстотнi умови договору, black market - чорний ринок.

Partial phraseological equivalents include semantically equivalent phraseological units of the Ukrainian and English languages, which are characterised by certain differences in terms of expression, which may be component or morphological in character. In most cases, the differences relate only to the component composition of the phraseological unit: e.g., the phraseological unit to balloon prices / роздувати ціни means to raise prices / піднімати ціни. The component composition of the both phraseological units coincide, the structural organisation is also the same, but there is an obvious difference in meaning of these two verbal components роздувати and balloon. Yet, both these verbs have the lexical meaning that describes an increasing process, which indicates their belonging to the similar semantic meaning.

Under non-equivalent phraseological units it is accepted to understand phraseological units that do not have a correspondence (equivalent) in the vocabulary of another language. The main ways of translating such units are tracing, descriptive translation and combined translation.

Tracing or literal translation of phraseological units, provided that there is a full or partial equivalent. Despite the presence of a full or partial equivalent, stable word combinations sometimes should be translated literary: administrator with the will annexed-lit. адміністратор спадщини із доданим заповітом; особа, призначена для виконання обов'язків душеприкажчика.

Descriptive translation of a phraseological unit is not a translation of the phraseological unit itself, but its interpretation, as is often the case with units that have no equivalents in the language of translation. These can be explanations, comparisons, descriptions, interpretations: action of the first impression - lit. diя першого подання; розгляд справи за відсутності прецеденту.

Conclusions. Thus, official business texts provide for strict standardization of language tools. Details of the official business text are mostly clichés, idioms or clichéd constructions, which achieve a certain syntactic and semantic formalisation of the text, which allows for relative unification and optimisation of business language. Translating official business texts is closely connected with the use of stable constructions, clichés and idioms, which belong to a differentiated special phraseology, without which the translation of a business text cannot be achieved with success. The very process of translating phraseological units cannot be reduced to the selection of «adequate linguistic equivalents», but is a complex process in which the translator's skills must be completed with the lingo-cultural knowledge, taking into consideration the interrelation of contacting cultures. Phraseological units used in official business style texts are mostly neutral. However, occasionally to 
create the desired effect can be used emotional-evaluative and expressive-figurative means, including idiomatic expressions that have lost their imagery. Translating official business texts that accompany the business process of an enterprise requires the correct use of semantic equivalents of terms, contextual trans- lation and interpretation of various abbreviations that can be used in the original language and, of course, correct text analysis to minimize not only lexical, but also syntactic, morphological, phraseological errors that may occur in translating. All this opens a promising perspective of the future studies.

\section{BIBLIOGRAPHY}

1. Арсентьева Е. Ф. Сопоставительный анализ фразеологических единиц, семантически ориентированных на человека, в русском и английском языках и вопросы создания русско-английского фразеологического словаря : дисс. ... д-ра филол. наук. Казань, 1993.

2. Влахов С. И., Флорин С. П. Непереводимое в переводе. Москва, 2009.

3. Переводческая коммуникация в XXI веке. Дискурсивные аспекты перевода: коллективная монография. Отв. ред. Н. М. Шутова. Ижевск : Издательский центр «Удмуртский университет», 2019. 252 с.

4. Шевина А. Б. Официально-деловой стиль. Матрица переводческих проблем : учебное пособие. Екатеринбург, 2010 .

5. Kutateladze M. Historical Review of Business English as a Part of English for Specific Purposes. Journal in Humanities. 2014. Vol. 3, Issue 1. P. 27-29.

\section{REFERENCES}

1. Arsenteva E. F. Sopostavitelnyiy analiz frazeologicheskih edinits, semanticheski orientirovannyih na cheloveka, v russkom i angliyskom yazyikah i voprosyi sozdaniya russko-angliyskogo frazeologicheskogo slovarya [Comparative analysis of phraseological units semantically oriented to a person in Russian and English and issues of creating a Russian-English phraseological dictionar]: diss. ... d-ra filol. nauk. Kazan, 1993. [in Russian].

2. Vlahov S. I., Florin S. P. Neperevodimoe v perevode [Untranslatable in translation]. M., 2009. [in Russian].

3. Perevodcheskaya kommunikatsiya v XXI veke. Diskursivnyie aspektyi perevoda [Translation communication in the XXI century. Discursive aspects of translation]: kollektivnaya monografiya. Otv. red. N. M. Shutova. Izhevsk : Izdatelskiy tsentr «Udmurtskiy universitet», 2019. 252 s. [in Russian].

4. Shevina A. B. Ofitsialno-delovoy stil. Matritsa perevodcheskih problem [Formal and business style. Matrix of translation problems]: uchebnoe posobie. Ekaterinburg, 2010. [in Russian].

5. Kutateladze M. Historical Review of Business English as a Part of English for Specific Purposes. Journal in Humanities. 2014. Vol. 3, Issue 1. P. 27-29. 